\title{
PEMANFAATAN BUDAYA DAN TEKNOLOGI LOKAL DALAM RANGKA PENGEMBANGAN SAINS
}

\author{
Hairida \\ Pend. Kimia, FKIP, Universitas Tanjungpura
}

\begin{abstract}
Science education can be developed based on the uniqueness and superiority of a region, including technology, culture and local (traditional). This study aims to identify and describe local cultural and technological environment of traditional agricultural communities the Malays and Dayaks in Pontianak regency still believed and used in maintaining life, and integrate the local culture and technology in the development of science-based learning the local culture. Qualitative approach to ethnographic studies (etnosains and etnoteknologi study) with emphasis on critical studies and interpretive conducted in order to explore local culture and technological environment of traditional agricultural communities the Malays and Dayaks in observation techniques and in-depth interviews. The results showed that in culture and traditional local technology community agricultural environment Malays and Dayak tribes identified science concepts that can be developed in science learning in schools.
\end{abstract}

Keywords: local culture, local technology, science

\section{PENDAHULUAN}

Perkembangan pendidikan
sains didorong oleh pesatnya
perkembangan ilmu pengetahuan dan
teknologi. Menurut Heddy Shri
Ahimsa-Putra (2003), persoalan
pengembangan teknologi yang lebih
didasarkan pada kehidupan
masyarakat di Indonesia mulai
banyak mendapat perhatian pada
akhir tahun 1970an, ketika
pembangunan yang banyak dilakukan
di Indonesia ternyata lebih diwarnai
oleh impor teknologi tinggi dari Barat
menimbulkan dampak yang
merugikan, antara lain: $(1)$
terabaikannya pengetahuan dan
teknologi etnik/lokal yang selama ini
menjadi tumpuan sebagian besar
masyarakat Indonesia dalam

beradaptasi dengan lingkungannya; (2) terdesaknya pengetahuan dan teknologi etnik/lokal oleh pengetahuan dan teknologi dari luar.

Seiring dengan perkembangan masyarakat dan teknologi, peralatan juga semakin modern yang digunakan manusia dalam memanfaatkan sumber daya alamnya. Manusia semakin leluasa ber-buat terhadap lingkungannya, sesuai dengan keinginan dan kebutuhannya. Kenyataan ini telah membawa kecenderungan terganggunya keseimbangan alam. Menurut Arif S (2001) kerusakan lingkungan yang disebabkan manusia, jika diidentifikasi umumnya disebabkan oleh ketidaktahuan masyarakat akan akibat dari tindakannya, misalnya 
kebiasaan masyarakat desa memanfaatkan sungai sebagai kakus, desakan kebutuhan hidup, kurang-nya pengetahuan tentang keseimbangan komponen dalam ekosistem, kepedulian terhadap kelestarian lingkungan yang ren-ah. Seharusnya melalui pendidikan sains kepedulian terhadap lingkungan telah tertanam, karena dikaji dari isi mata pelajaran, maka sains (fisika, kimia dan biologi) merupakan mata pelajaran yang sarat akan nilai-nilai kearifan budaya masyarakat Indonesia. Sekarang ini cenderung terabaikan nilai-nilai luhur tersebut. Dalam proses belajar mengajar IPA, aplikasinya cenderung menekankan aspek kognitif saja, artinya konsep-konsep yang diajarkan hanya sekedar pengetahuan, kurang dihayati dan direalisasikan sebagai sikap dan perilaku yang nyata.

Ragam antropologis saat ini telah menjadi permasalahan yang cukup aktual untuk dikaji, salah satu ragam yang menonjol adalah ragam etnik yang implikasinya akan segera terlihat pada ragam budaya, langgam hidup, pola berpikir dan pengambilan keputusan. Ragam etnik pada bangsa Indonesia, sampai saat ini belum menjadi perhatian dalam penentuan pola pembelajaran. Pola berpikir kritis tidak dapat optimal berkembang pada etnik yang budayanya justru tidak mendukung (Wuryadi, 2003). Latar belakang budaya yang dimiliki oleh siswa berpengaruh terhadap proses pembelajaran sains dalam usahanya menguasai konsep-konsep sains yang diajarkan di sekolah.

Dalam perspektif anthropologi dinyatakan bahwa pembelajaran sains dianggap sebagai transmisi budaya (cultural transmission) dan sebagai penguasaan budaya (cultural acquisition). Dengan demikian proses KBM (kegiatan belajar mengajar) di kelas dapat diibarat-kan sebagai proses pemindahan dan perolehan budaya dari guru dan oleh siswa. Dalam pembelajaran sains, transfer pengetahuan apapun bentuknya harus mempertimbangkan latar belakang budaya siswa (Wahyudi, 2003). Hal ini sejalan dengan pendapat Cobern (1994) bahwa cara seseorang memahami hubungan seseorang dengan dunianya (lingkungannya) dan juga cara pandang seseorang terhadap hubungan sebab akibat, ruang, dan waktu adalah sangat dipengaruhi oleh asal-usul budayanya.

Pengaruh latar belakang budaya yang dimiliki siswa terhadap proses pembelajaran IPA ada dua macam. Pertama, pengaruh positif akan muncul jika materi pada pembelajaran IPA di sekolah yang sedang dipelajari selaras dengan pengetahuan (budaya) siswa seharihari. Pada keadaan ini proses pembelajaran mendukung cara pandang siswa terhadap alam sekitarnya. Proses pembelajaran yang seperti ini disebut dengan proses inkulturasi (enculturation). Sebaliknya, yang kedua, proses pembelajaran IPA di kelas menjadi 'pengganggu' ketika materi pelajaran IPA tidak selaras dengan latar belakang budaya yang sudah mengakar pada diri siswa, serta guru berusaha untuk 'memaksakan' kebenaran materi pelajaran IPA (budaya Barat) dengan cara memarjinalisasikan pengetahuan (budaya) siswa sebelumnya. Proses pembelajaran seperti ini disebut asimilasi (Cobern dan Aikenhead, 1998). 
Dalam proses pembelajaran sains, guru memegang peranan utama sebagai perantara dalam penyampaian antara budaya barat (sains barat) dan budaya lokal dengan siswanya. Sehubungan dengan proses ini, Snively dan Corsiglia (2001) mengidentifikasi peran guru sains yaitu : (1) memberi kesempatan pada siswa untuk mengekspresikan pikiranpikirannya, untuk mengakomodasi konsep-onsep atau keyakinan yang dimi-iki siswa yang berakar pada budaya lokal, (2) menyajikan kepada siswa contoh-contoh keganjilan yang sebenarnya hal biasa menurut konsepkonsep sains Barat, (3) berperan untuk mengidentifikasi batas budaya yang akan dilewatkan serta menuntun siswa melintasi batas budaya, sehingga membuat masuk akal bila terjadi konflik budaya yang muncul, (4) mendorong siswa untuk aktif bertanya, (5) memotivasi siswa agar menyadari akan pengaruh positif dan negatif sains Barat dan teknologi bagi kehidupan dalam dunianya.

Sejak diberlakukannya KBK (Kurikulum Berbasis Kompetensi), sebenarnya pemerintah sudah memberikan peluang pada daerah untuk mengem-bangkan silabus dan bahan ajar sendiri (Depdiknas, 2001). Kurikulum dilaksanakan dengan mendayagunakan kondisi alam, sosial dan budaya serta kekayaan daerah untuk keberhasilan pendidikan dengan muatan seluruh bahan kajian secara optimal (Peraturan Menteri No. 22 Tahun 2006 tentang Standar Isi). Hal ini berarti setiap daerah dapat mengembangkan kurikulum IPA sesuai tuntutan dan keunikan atau keunggulan daerahnya dalam prosen belajar mengajar IPA.
Kalimantan Barat memiliki kesempatan untuk membuat dan mengembangkan perangkat pembelajaran untuk mengakomodasi potensi dan keunggulan daerahnya dalam mata pelajaran sains. Hal ini akan memberikan harapan sekaligus tantangan bagi penyelenggara pendidikan di daerah, termasuk di dalamnya para pelaksana dan pengembang kurikulum. Sebagai konsekuensinya, pada tingkatan operasional, untuk menampilkan keunikan dan keung-gulan daerahnya masing-masing penyelenggaraan dalam khususnya mata pelajaran sains.

Dimensi manfaat dari suatu ilmu adalah penyesuaian dengan kondisi dan kebutuhan masyarakat. Dimensi Ilmu yang tidak bermanfaat bagi masyarakatnya akan kehilangan momentum pengembangannya (Wuryadi, 2003). Pendidikan sains adalah suatu ilmu, maka memiliki karakteristik yang berkaitan dengan manfaat tersebut. Konsekuen-sinya, perancang proses pembelajaran perlu menyiapkan lebih banyak alternatif agar memperoleh hasil pembelajaran yang optimal. Kurikulum baru (KTSP) memberikan kebebasan kepada daerah, sekolah, dan guru untuk mengembangkan silabi, bahan ajar, maupun model pembelajarannya sesuai kebutuhan sekolah, namun tetap berada dalam lingkup kompetensi yang ditetapkan dalam kurikulum baru (Indra Djati Sidi, 2002). Jadi untuk meningkatkan relevansi kurikulum dan kebutuhan masyarakat apat dikembangkan perangkat pembelajaran dengan menggunakan sumber-sumber belajar seperti masalah-masalah/isu-isu yang berkembang di masyarakat, potensi 
daerah, kebutuhan masyarakat, dan budaya dan teknologi yang berkembang di dalam masyarakat.

Belajar merupakan suatu proses dimana siswa menggunakan pengetahuan sebelumnya untuk mengasimilasi pengetahuan baru dan mengkonstruksi dengan pengertian atau ide mereka sendiri. Untuk menjembatani kesenjangan antara harapan pembelajaran yang dituntut pada abad pengetahuan dengan kenyataan yang dihadapi pada proses pembelajaran saat ini yang masih banyak menggunakan paradigma lama, maka pengembangan pembelajaran sains berbasis budaya lokal dapat mengakomodir sumbersumber belajar yang terkandung dalam budaya lokal. Misalnya budaya lokal masyarakat di lingkungan pertanian suku melayu dan dayak di kabupaten Pontianak. Salah satu faktor penting pada suku ini dalam mewujudkan kebudayaan dan lingkungan hidupnya adalah pertanian. Berbagai mitos, kebiasaan, keyakinan, dan keteram-pilan dalam pertanian yang masih diyakini dan berkembang di masyarakat setempat dapat dijadikan sumber belajar dalam pembelajaran sains di sekolah, khususnya di SD kabupaten Pontianak, guna mening-katkan kualitas proses dan hasil belajar sains (IPA).

Pembelajaran sains melalui model pembelajaran IPA berbasis budaya lokal, siswa dihadapkan pada budaya setempat sebagai bagian dari proses pembelajaran. Siswa mendiskusikan secara kelompok permasalahan di masyarakat yang dikaitkan dengan budaya lokal masyarakat setempat. Dalam diskusi, diharapkan dapat diubah persepsi sains asli (budaya lokal) sebagai mitos, tahyul, mistis dan persepsi negatif lainnya oleh siswa. Sebelum pembelajaran dilaksanakan, guru dianjurkan untuk memilih konsepkonsep atau topik-topik sains yang ada hubungannya dengan lingkungan sosial budaya setempat. Topik-topik itu dapat diperoleh melalui identifikasi budaya lokal yang ada di masyarakat, baik melalui nara sumber maupun melalui observasi budaya yang ada di lingkungan.

Aspek budaya dalam pendidikan IPA merupakan strategi penciptaan lingkungan belajar dan perancangan pengalaman belajar yang mengintegra-sikan budaya setempat sebagai bagian dari proses pembelajaran. Budaya menjadi sebuah media bagi siswa untuk mentransformasikan hasil observasi mereka ke dalam bentuk dan prinsip yang kreatif tentang alam (Fadli, M, 2008). Aspek budaya lokal masyarakat suku Melayu dan Dayak berupa kebiasaan-kebiasaan, normanorma, sikap, keper-cayaan, keyakinan, teknologi, pandangan alam semesta dapat dijadikan sebagai sumber belajar dalam pendidikan sains di sekolah.

Menurut perspektif antropologi kebudayaan, pengajaran IPA dipandang sebagai transmisi budaya dan belajar sains sebagai pemerolehan kebudayaan, dimana kebudayaan berarti 'an ordered system of meaning and simbols (Wolcott, 1991; Geertz, 1973; Spindler, 1987 dalam Wahyudi, 2003). Berdasarkan hasil penelitian, sejumlah atribut-atribut budaya seperti kolunikasi (psikolinguistik dan sosiolinguistik), struktur sosial (otoritas, interaksi, partisipan), 
keterampilan (psiko-motorik dan kognitif), kebiasaan-kebiasaan, norma-norma, sikap, kepercayaan, keyakinan, nilai harapan materi artifact, teknologi, pandangan alam semesta sekelompok orang yang telah terpola dalam suatu masyarakat dan diwariskan dari generasi ke generasi serta memberikan identitas pada komunitas pendukungnya (Cobern \& Aikenhead, 1996; Prosser dalam Supriadi, 2001).

Masyarakat adat memiliki strategi memelihara hutan, menjaga keseimbangan ekosistem, tetap menanam varitas padi lokal sehingga keanekaragaman hayati terjaga. Namun, dalam pendidikan formal di sekolah, kearifan lokal seperti di atas tidak terungkap. Pendidikan sains formal lebih berkonsentrasi pada upaya beradaptasi dengan perkembangan ilmu penge-tahuan dan teknologi yang bersandar pada pola pendidikan sains di negara maju. Adimassana (2000:30) mengatakan bahwa pendidikan dianggap telah gagal dalam menanamkan nilai-nilai luhur. Situasi pendidikan kita dalam 35 tahun terakhir ini kurang menumbuhkan kesadaran akan nilainilai dan formal. Hal ini didukung oleh hasil studi yang dilakukan Suastra, dkk (2003) bahwa sebagaian besar $(90 \%)$ tujuan pembelajaran sains di sekolah lebih diarahkan pada pencapaian pengetahuan sains (produk) saja. Hasil penelitian pendahuluan yang dilakukan Hairida, dkk (2007) ditemukan bahwa sebagian besar siswa SD (65\%) di kabupaten Pontianak tidak dapat menyelesaikan soal-soal sains yang berkaitan dengan kehidupan masyarakat dan teknologi, karena pengajaran yang dilakukan guru jauh dari kehidupan siswa sehari-hari. Penyebabnya, guru kesulitan dalam mengim-plementasikan pembelajaran sains yang mengkaitkan konsep dengan kehidupan masyarakat dan teknologi. Akibatnya konsep yang diajarkan tidak dikaitkan dengan permasalahan yang terjadi di masyarakat, keterampilan proses IPA kurang diperhatikan oleh guru, belajar konsep-konsep IPA hanya yang ada dalam buku saja, jauh dari kehidupan siswa sehari-hari (Hairida, 2008).

$$
\text { Indonesia merupakan }
$$

masyarakat yang memiliki beragam budaya dan teknologi lokal yang dapat dikembangkan dalam kehidupan Agar budaya yang berupa kearifan terhadap alam tidak punah, maka penting di lakukan pelestarian terhadap nilai-nilai luhur tersebut. Nilai-nilai luhur perlu ditanamkan dan disosialisasikan kepada siswa melalui proses pembelajaran. Oleh karena itu penelusuran atau penggalain mengenai budaya lokal atau pengetahuan asli (indigenous knowledge) suatu masyarakat penting untuk diteliti. Pembelajaran sains di sekolah kurang mem-perhatikan budaya lokal yang berkembang di masyarakat yang ada, karena keterbatasan guru dalam mengkaitkan konsep, proses dan konteks. Akibatnya pemahaman siswa tentang fenomena alam menjadi tidak bermakna.

Pendidikan sains di sekolah lebih banyak memaparkan pada perkembangan ilmu dan teknologi dengan bercermin pada pola pendidikan sains di negara barat. Oleh karena itu penggalian pengetahuan asli (indigenous knowledge) di suatu masayarakat penting untuk diteliti dan diungkapkan dalam pendidikan sains 
di sekolah. Hal ini memungkinkan, sebab indigenous knowledge dapat memperkuat pendidikan sains (George, 2001). Pemanfaatan pengetahuan asli sesuai dengan prinsip pengembangan KTSP yang menyatakan bahwa kekayaan alam maupun budaya merupakan landasan perumusan kurikulum dalam mata pelajaran sains. Kenyataanya, guru hanya mementingkan belajar MIPA hanya untuk kepentingan MIPA sebagai bidang ilmu dan untuk pemenuhan kurikulum serta untuk siswa memperoleh nilai, padahal belajar MIPA sebagai sebuah ilmu yang dipelajari di sekolah semestinya tidak terlepas dari situasi lokal dimana sekolah itu berada atau tidak terlepas dari komunitas asal siswa (Pannen, 2002).

Dengan demikian, peneliti berasumsi bahwa dari berbagai aktifitas dan kebiasaan-kebiasaan, baik yang berkaitan dengan budaya maupun teknologi lokal yang dilakukan masyarakat lingkungan pertanian pada suku Melayu dan Dayak di Kabupaten Pontianak terkandung konsep-konsep sains asli yang dapat diterapkan dalam pembelajaran sains di sekolah.

Berdasarkan hal tersebut maka dalam penelitian ini dilakukan penelusuran budaya lokal di lingkungan masyarakat pertanian suku Melayu dan Dayak di Kabupaten Pontianak. Hasil penelitian ini diharapkan dapat mem-berikan gambaran menyeluruh tentang budaya dan teknologi lokal yang berkembang dalam masyarakat tradisional lingkungan pertanian suku Melayu dan Dayak di Kabupaten Pontianak Kaliman-tan Barat, sehingga dapat direkonstruksi dan dikembangkan dalam pembelajaran sains di sekolah. Secara lengkap perma-salahan penting yang perlu dikaji dalam penelitian ini adalah :

a. Bagaimana budaya budaya dan tekno-logi lokal yang masih berkembang dan digunakan masyarakat tradisional lingkungan pertanian suku Melayu dan Dayak di kabupaten Pontianak?

b Apakah budaya dan teknologi lokal masyarakat tradisional lingkungan pertanian suku Melayu dan Dayak di Kabupaten Pontianak Kalimantan Barat memiliki kesepadanan dengan konsepkonsep sains di sekolah?

c. Bagaimana pengintegrasian sains asli dan teknologi lokal masyarakat ling-kungan pertanian suku Melayu dan Dayak di Kabupaten Pontianak Kalimantan Barat dalam pengem-bangan pembalajaran sains berbasis budaya lokal di sekolah?

\section{METODE PENELITIAN}

\section{Pendekatan Penelitian}

Penelitian ini menggunakan pendekatan kualitatif melalui studi etnografi dalam mengungkap budaya dan teknologi lokal masyarakat lingkungan pertanian suku Melayu dan Dayak di Kabupaten Pontianak yang masih diyakini dan digunakan. Melalui studi ini dimungkinkan untuk melakukan analisis, mendeskripsikan dan menjelaskan hubungan-hubungan yang terjadi yang membentuk fenomena pendidikan sains sebagai rekonstruksi budaya dari unsur-unsur sosial yang nyata, pengalaman subyektif yang melandasi tindakan tersebut, dan kondisi-kondisi konteks sosial-budaya yang melandasinya (Carspecken, 1996). Pada dasarnya 
etnosains (ethnoscience) juga sering disebut sebagai etnografi baru (The new ethnography) dalam konteks kajian antropologi (S. Arifianto, 2005).

Hasil penelusuran terhadap berbagai budaya lokal masyarakat Dayak kanayatn selanjutnya di sepadanankan dengan konsep-konsep IPA dalam kurikulum dan dirancang perangkat pembelajaran IPA berbasis budaya lokal.

\section{Setting dan Subyek Penelitian}

Setting penelitian adalah masyarakat tradisional lingkungan perta-nian suku Melayu dan Dayak di Kabupaten Pontianak. Adat istiadat masyarakat setempat yang diturunkan secara turun temurun dalam bertani, pengolahan kelapa dan pengobatan masih dipegang kuat oleh mereka. Bertani merupakan mata pencaharian utama masyarakat tersebut. Mereka menggarap lahan kering (ladang) dan lahan basah (sawah), khusus untuk menanam padi. Suku Dayak dalam penelitian ini adalah semua suku Dayak yang ada di Kabupaten Pontianak, yang masih memegang tinggi budaya setempat.

Penelitian ini melibatkan informan kunci dan informan lainnya yang dapat memberikan informasi sesuai dengan permasalahan yang diteliti. Informan kunci adalah tokoh masyarakat/adat, tokoh pendidikan dan tokoh agama dan beberapa petani (suku Dayak dan Melayu). Informan lainnya ditentukan berdasarkan informasi dari informan kunci dengan menggunakan prinsip purposive dan snowball sampling (Patton, 1982).

\section{Keabsahan Data}

Data yang dianalisis dalam penelitian kualitatif memerlukan empat kriteria keabsahan, yaitu: kredibilitas/ derajat kepercayaan (validitas internal), transferabilitas (validitas eksternal), dependabilitas/ketergantungan (reliabilitas), dan konfirmabilitas/ kepastian (obyektivitas) (Moleong, 1990). Sehubungan dengan hal itu, dilakukan hal-hal sebagai berikut:

a. Untuk memenuhi kriteria kepercayaan terhadap data yang sudah dikumpulkan, dilakukan beberapa upaya antara: 1) melakukan penelitian di lapangan dalam waktu yang relatif lama.

b. Melakukan Triangulasi sumber data dan metode. Triangulasi sumber data dilakukan dengan membandingkan data yang saling melengkapi, yang diperoleh dari informan, partisipan, dan responden dalam berbagai setting.

c. Untuk meningkatkan kadar ketergantungan dan kepastian hasil penelitian dilakukan dengan review terhadap seluruh jejak aktivitas penelitian.

\section{Teknik dan Alat Pengumpul Data}

Untuk menjawab permasalahan tentang budaya lokal yang masih diyakini dan digunakan dalam mempertahankan kehidupannya digunakan teknik observasi, wawancara, studi dokumenter, dan pengukuran dengan alat pengumpul data berupa perangkat observasi dan wawancara dan alat 
perekam (tape recorder, kamera, handycame). Observasi partisipasi aktif dilakukan agar dapat diungkapkan unsur-unsur sains asli (budaya lokal) yang tersembunyi dari aktifitas yang dilakukan masyarakat petani yang belum dapat diungkapkan oleh informan. Dalam kegiatan ini, alat pengumpul data yang digunakan adalah perangkat observasi berupa catatan dan alat perekam (kamera dan handycame). Wawancara mendalam dilakukan untuk mengungkapkan apa yang tersembunyi dalam diri informan tentang pandangan mereka tentang gejala alam, tatacara bertani, pengolahan dan pemanfaatannya. Menurut Faisal (1990), wawancara dapat diungkapkan berbagai informasi yang bersifat lintas waktu yang berkaitan dengan masa lampau, masa kini, dan masa yang akan datang. Informan kunci adalah tokoh masyarakat/adat, tokoh pendidikan dan tokoh agama, beberapa warga masyarakat petani yang mampu memberikan informasi sesuai dengan masalah penelitian. Informan lainnya ditentukan berdasarkan informasi dari informan kunci dengan menggunakan prinsip purposive dan snowball sampling (Patton, 1982). Alat pengumpul data yang digunakan adalah perangkat wawancara yang meliputi catatan, camera, tape recorder, handycame. Untuk melengkapi data penelitian, akan digunakan studi dokumenter terhadap aturan-aturan tertulis maupun tidak tertulis, monografi desa, peta, data statistik, dan buku yang berkaitan dengan masalah penelitian.

\section{Analisa Data}

Analisa data dalam penelitian ini dilakukan secara terus menerus sejak awal sampai akhir penelitian. Berbagai tindakan, tidak saja berbentuk penggalian data secara intensif, tetapi juga disertai dengan kategorisasi, penyusunan dan analisa data. Selain itu, dilakukan pula interpretasi data, yaitu mencari makna suatu perilaku yang tampak, sesuai dengan konteks sistem sosiokultural masyarakat setempat. Melalui cara ini, diharapkan diperoleh deskripsi teori tentang budaya dan teknologi lokal yang benar-benar terkait dengan sistem sosiokultural masyarakat tradisional lingkungan pertanian suku Melayu dan Dayak di kabupaten Pontianak.

\section{HASIL}

Mata pencaharian utama masya-rakat di kabupaten Pontianak adalah bertani. Mereka menggarap lahan kering (ladang) untuk ditanami padi, berbagai macam sayuran, dan tanaman lain, seperti mentimun, labu bayam, sawi, ubi jalar, ubi kayu, dan tebu. Mereka juga menggarap lahan basah (sawah), khusus untuk menanam padi. Tradisi mengadakan acara tolak bala di lokasi persawahan untuk penaman padi perdana di Desa Sungai Bakau Besar Laut Kabupaten Pontianak rutin dilakukan setiap musim tanam tiba. Acara diiringi dengan pembacaan doa untuk menghindari musibah supaya dari bencana alam dan serangan hama terhadap tanaman padi (Johan Wahyudi, 2008).

Masyarakat adat memiliki strategi dalam memelihara palsma nutfah seperti menanam varietas padi lokal sehingga keanekaragaman hayati terjaga. Dalam penelitian Sri Astuti tentang Eksplorasi Plasma Nutfah Tanaman Pangan di Provinsi 
Kalimantan Barat ditemukan bahwa adat dan kebiasan masyarakat yang ditemui di beberapa daerah di Kalimantan Barat (khususnya di Kabupaten Pontianak) dan masih berkembang antara lain: 1) Pantang menjual padi atau beras, pantang menanam padi dua kali setahun. Hal ini disebabkan karena petani masih menanam padi berumur panjang (kurang lebih 6 bulan) dan mereka belum memahami cara pengendalian hama dan penyakit secara terpadu. Menanam padi secara terus menerus tanpa pengendalian hama dan penyakit secara baik maka serangan hama dan penyakit pada penanaman berikutnya akan lebih besar, 2) Pantang menggunakan sabit untuk panen padi. Kondisi ini terjadi karena padi yang ditanam adalah varietas lokal yang pemasakan bulirnya tidak seragam, sehingga jika dipanen dengan sabit maka mutu hasilnya kurang baik karena adanya butir hijau. Lain halnya padi unggul yang pemasakan bulirnya serempak, 3) Pan-tang mengeluarkan benih pada sore/malam hari. Mereka beranggapan bahwa benih mempunyai ruh sehingga harus istirahat pada sore/malam hari dan tidak boleh diganggu sampai esok harinya (Sri Astuti, 2004).

Salah satu acara yang berkaitan dengan keagamaan pada masyarakat tradisional suku Melayu adalah acara Tumpang Negeri, mempunyai dua dimensi. Pertama, merupakan suatu doa, supaya terhindar dari segala balak, bencana alam dan penyakit. Kedua, permohonan keselamatan dan kesejah-teraan. Pelaksanaan Tumpang Negeri, biasanya dilaksanakan pada akhir atau awal tahun, berdasarkan situasi alam. Biasanya melihat tanda hujan dan itu menjadi syarat untuk penentuan acara. Kalau hujannya banyak atau sedikit, ada penentuannya. Hal itu merupakan upaya menyiasati tanda-tanda alam. Sifat acara ini tolak balak. Bila hujan terlalu banyak, maka dengan pelaksanaan Tumpang Negeri, tidak akan terjadi banjir. Tapi, kalau tidak turun hujan, diharapkan bisa turun. Masyarakat bertani berpendapat gejala alam sangat mempengaruhi kegiatan bertani dan juga hasil pertanian mereka. Sebagai contoh, kegiatan bertani kadang dilakukan jika hari tidak hujan. Jika hujan maka petani tidak bisa turun ke ladang. Selain itu, jika musim hujan, kegiatan membuka lahan baru untuk bertani juga akan terhambat. Tetapi, jika musim kemarau juga tidak terlalu bagus. Tanaman padi akan kekeringan, dan hasil panen tidak maksimal. Oleh sebab itu, jika mereka bijaksana menata alam mereka akan mendapat rezeki dari alam, dibantu dan bahkan akan dilindungi oleh alam. Hal ini ada kaitannya dengan kepercayaan mereka, yang menganggap bahwa alam itu, baik yang nyata maupun yang gaib, merupakan sumber dan basis kehidupan. Dari contoh tersebut, dapat dikatakan bahwa gejala alam juga merupakan salah satu faktor yang mempengaruhi berhasil atau tidaknya kegiatan bertani. Bagi masyarakat petani, keberhasilan dalam bertani merupakan suatu anugerah, karena hasil pertanian ini digunakan untuk memenuhi kebutuhan hidup sehari-hari. Untuk memulai tahun perladangan, masyarakat petani Dayak mengamati 
cuaca, bintang, keadaan flora dan fauna.

Konsep-konsep tradisional yang teridentifikasi dari masyarakat
Melayu dan Dayak di lingkungan pertanian yang berkaitan dengan sains sekolah dapat dilihat pada tabel berikut.

Tabel 1. Konsep Sains Masyarakat Melayu dan Dayak di Lingkungan Pertanian yang Berkaitan dengan Sains di SD

\begin{tabular}{|c|c|c|}
\hline No & Sains Masyarakat & Sains Sekolah \\
\hline 1 & Varietas padi lokal & $\begin{array}{l}\text { Saling Ketergantungan, Pelestarian Sumber } \\
\text { Daya Alam }\end{array}$ \\
\hline 2 & $\begin{array}{l}\text { Pemilihan tempat } \\
\text { tanam }\end{array}$ & Keseimbangan Alam \\
\hline 3 & Ladang Berpindah & $\begin{array}{l}\text { Rantai Makanan/Ekosistem/Sumber Daya } \\
\text { Alam }\end{array}$ \\
\hline 4 & $\begin{array}{l}\text { Tahap Bertani } \\
\text { (Pemupukan) }\end{array}$ & Kesuburan Tanah \\
\hline 5 & $\begin{array}{l}\text { Tahap Bertani } \\
\text { (menjaga) }\end{array}$ & Pemberantasan Hama \\
\hline 6 & Penyediaan pupuk & Cara-cara pembuatan pupuk alami \\
\hline 7 & $\begin{array}{l}\text { Pertumbuhan dan } \\
\text { Perkembangan Padi }\end{array}$ & Proses Fotosintesis \\
\hline 8 & Tahap Menebang & Peran Cahaya/Fotosisntesis \\
\hline 9 & $\begin{array}{l}\text { Pandangan terhadap } \\
\text { Alam Semesta }\end{array}$ & Pelestarian Hutan \\
\hline
\end{tabular}

\section{PEMBAHASAN}

Praktek bertani merupakan bagian dari aktivitas sehari-hari bagi keluarga petani suku Melayu dan Dayak. Pulang sekolah, siswa membantu orang tuanya di ladang atau di sawah. Aktivitas siswa banyak dilakukan di sawah/ladang. Kegiatan di sawah/ladang banyak mem-beri pengetahuan dan pengalaman bagi siswa tentang berbagai permasalahan pertanian secara langsung. Mulai dari mengamati alam, pemilihan lahan, persiapan benih, pemupukan dan pemanenan.

Agar pemahaman konsep, kete-rampilan proses siswa, dan penerapan konsep lebih terpadu dalam pembelajaran sains, maka konsep-konsep pengetahuan sebelumnya perlu dijelaskan hubungan sebab akibatnya dalam pembelajaran sains. Kegiatan ini akan membentuk konsepsi ilmiah yang memiliki kaitan sebab-akibat, yang pada akhirnya dapat menjadi teori dalam khasanah penge-tahuan ilmiah. Dengan demikian pengetahuan tradisional yang awalnya meru-pakan milik masyarakat adat tertentu, dapat disebarkan kepada masyarakat yang lebih luas.

Aspek budaya dalam pendidikan sains merupakan strategi penciptaan lingkungan belajar dan perancangan pengalaman belajar yang mengintegrasi-kan budaya 
setempat sebagai bagian dari proses pembelajaran. Budaya pertanian masyarakat Melayu dan Dayak menjadi sebuah media bagi siswa untuk mentransformasikan hasil pengamatan mereka ke dalam bentuk dan prinsip yang kreatif tentang alam. Dengan demikian, dari berbagai aktifitas dan kebiasaankebiasaan, yang dilakukan masyarakat Dayak Kanayatn di Kalimantan Barat terkandung konsep-konsep sains asli yang dapat dikembangkan dalam pembelajaran sains, guna meningkatkan kualitas proses belajar mengajar sains. Selain itu, konsep sains asli penduduk dalam mengelola sumber daya alam, dapat dijadikan contoh dalam memperbaiki lingkungan.

\section{Varietas padi lokal-Saling Ketergantungan, Pelestarian Sumber Daya Alam}

Masyarakat Dayak adalah kambing hitam perusak hutan karena mereka berladang berpindah (Herwasono Soedjito, 1996). Pandangan seperti ini mengakibatkan mereka seringkali dianggap sebagai pemusnah plasma nutfah. Walaupun ada yang meniru cara seperti ini, namun pada prakteknya mereka tidak menghiraukan pakem dan kaedah ladang daur ulang masyarakat tradisional Dayak, sehing-ga hasilnya adalah berladang berpin-dah yang beberapa diantaranya dapat merusak ekosistem hutan. Sebenarnya kalau dikaji lebih mendalam, ternyata masyarakat tradisonal Dayak melakukan perladangan daur ulang, bukannya membabat hutan dengan membabibuta. Tradisi berladang daur ulang ini selalu mensyaratkan pena- naman jenis tumbuhan yang beraneka ragam sebagai strategi dalam perse-diaan pangan. Sistem daur ulang ini ternyata memperkaya variasi jenis tumbuhan lainnya seperti tumbuhan obat, racun, serta bahan peralatan dan bangunan. Jadi masyarakat Dayak pada hakekatnya melalui praktek ladang daur ulang justru ikut membantu melestarikan keanekara-gaman plasma nutfah.

\section{Pemilihan Tempat Tanam Keseimbangan Alam}

Aktifitas berladang tidak bisa terlepas dari hutan. Tanpa hutan, maka tidak akan ada ladang. Dalam berladang lahan yang dibutuhkan tidak luas maksimal hanya 1,5 hektar, setelah panen ladang ditanami pepohonan seperti karet, tengkawang, rotan, dan aneka jenis buah. Dalam waktu 10-15 tahun lahan tersebut telah berubah menjadi hutan kembali. Menanami ladang dengan pepohonan adalah wajib bagi setiap peladang. Kewajiban itu tidak terlepas dari adat yang dipegang oleh masyarakat Dayak. Hutan adalah eksistensi masyarakat Dayak. Hutan bagi masyarakat Dayak merupakan dunia, sumber kehidupan. Kedudukan dan peran hutan seperti itulah yang mendorong masyarakat Dayak untuk memanfaatkan hutan di sekitar mereka dan sekaligus menumbuhkan komitmen untuk menjaga kelestariannya demi keberadaan dan kelanjutan hidup hutan itu sendiri. Untuk melakukan hal itu, masyarakat Dayak dibekali oleh mekanisme alamiah dan nilai budaya yang mendukung pemanfaatan hutan demi kelanjutan hidup dan pelestarian alam. Sebuah nilai keseimbangan untuk menjaga 
alam dapat ditemukan dengan jelas dalam pola pembukaan lahan, masyarakat harus memperha-tikan alam dan sesama manusianya, tidak boleh berlebihan atau rakus dan tetap harus memikirkan keberlanjutan alam. Pembatasan ini dapat menjaga keseimbangan ekosistem hutan tidak rusak. Abu dari pembakaran hutan menjadi pupuk alami yang mengakibatkan hasil ladang cukup dan lingkungan pertanian kembali subur untuk manusia bertahan hidup di lingkungannya. Sesudah panen padi atau jagung tanahnya bisa dikem-balikan menjadi hutan lagi dalam beberapa waktu. Seandainya bekas ladang sudah menjadi hutan dengan pohon yang sudah cukup tinggi, hutan itu bisa dibuka kembali untuk memenuhi kebutuhan primer masyarakat. Pertemuan untuk memilih lahan dapat berjalan berbulan-bulan dengan memperhitungkan banyak hal. Misalnya kemiringan lahan, kesuburan tanah dengan indikator berupa warna atau jenis tumbuhan tertentu sebagai penciri. Masyarakat tradisional di ling-kungan pertanian suku Dayak dan Melayu di kabupaten Pontianak mengetahui hubungan antara sistem akar dan produksi padi. Mereka enggan menanam padi di lahan yang masih mempunyai lapisan akar segar dan tebal, atau dalam istilah lokal disebut atub. Pada tahun pertama hasil panen padi pasti tidak banyak, karena kemungkinan belum optimal-nya ujung akar padi mencapai lapisan tanah karena terhalang oleh lapisan atub yang tebal. Alasan lainnya, atub tersebut belum terurai, sehingga hara tanah yang dapat diserap akar padi menjadi terbatas pula atau dalam istilah ilmu tanah, hara yang tersedia di bawah lapisan atub menjadi sedikit.

\section{Ladang Berpindah-Rantai Makanan/Ekosistem}

Dalam mengelola lokasi pertanian lahan kering, masyarakat Dayak pada umumnya melakukan ganti lahan atau gilir balik artinya lokasi yang dikelola tahun ini akan siap diolah kembali sekitar tiga tahun/lebih yang akan datang. Tujuannya untuk menjaga agar lahan tersebut tetap subur tanpa harus menggunakan pupuk buatan, dan keseimbangan ekosistem tetap terjaga. Untuk lahan basah/sawah, petani masyarakat Dayak pada umumnya melakukan setahun sekali. Tujuannya agar lahan sawah tersebut tetap subur tanpa harus menggunakan pupuk buatan, yaitu dengan membuka bendungan air supaya lahan/sawah tetap basah dan subur. Adapun manfaat ladang berpindah bagi petani yang menanam padi uma adalah mencari kualitas hasil panen yang lebih baik. Di karenakan ladang yang baru dibuka sebagai ladang berpindah memiliki unsur hara yang masih komplet, sehingga padi yang di tanam akan subur. Sistem ladang berpindah itu sebagai sistem pertanian asli terpadu (integrated indigenous farming system). Bukan ladang berpindah tetapi ladang bergilir. Sebab sistem perladangan dari masyarakat Dayak ini berladang di lahan lain untuk memberi kesempatan lahan lama itu cukup tua (10-15 tahun) yang nantinya akan mereka ladangi lagi. Sistem pertanian ini merupakan jawaban yang tepat bagi perjuangan mempertahankan kehidupan di atas 
tanah yang relatif kurang subur. Daur perladangan sekitar 10-15 tahun secara teratur menyebabkan hutan subur berkelanjutan.

\section{Tahap Bertani (Pemupukan)- Kesuburan Tanah}

Menurut Sitorus (2006), proses penyuluhan pertanian terutama selama periode "Revolusi Hijau" adalah proses pembodohan dan pelemahan secara sosial-budaya. Dalam periode tersebut petani padi telah kehilangan "pengetahuan dan teknologi asli" karena diganti-paksa dengan "pengetahuan dan teknologi asing" melalui proyek modernisasi petanian

(http://pse.litbang.deptan.go.id/ind/p dffiles/SEM 31-08-06.pdf). Sistem bertani non-organik telah meninggalkan dampak negatif secara ekonomis, ekologis, genetik, dan sosial budaya (Iskandar, 2000). Pertanian organik selain ramah dengan lingkungan, juga tidak membahayakan manusia itu sendiri bila mengkon-sumsi hasil-hasil pertanian organik, seperti padi/beras, sayuran dan buah-buahan. Hal ini tentu saja tidak dapat dilaksanakan apabila kondisi atau ketersediaan lahan tidak mendukung. Masyarakat Dayak Kanayatn di Kalimantan Barat, sejak dahulu kala hingga sekarang masih melakukan cara-cara pertanian organik ini, karena alam di Kalimantan Barat masih sangat mendukung proses kegiatan pertanian organik baik cuaca, relief, kesuburan tanah, pengairan dan lainlain. Selain potensi wilayah yang sangat mendukung, keterkaitan pertanian organik inipun sangat identik dengan tradisi dan budaya Dayak Kanayatn seperti memelihara/ melestarikan Timawakng, Kompokng, Padagi, Paburungan dan lain-lain yang bersahabat dengan alam. Proses pertanian organik ini selalu meli-batkan sang pencipta. Hasil pertanian organik tidak hanya menghasilkan padi, tetapi juga dapat menghasilkan komoditi lain seperti sayuran (bayam, ketimun, ubi talas, ubi jalar, ubi kayu, cabe, terung dan lain-lain), tanaman lainpun selalu ditanam secara organik seperti buahbuahan dan tanaman keras lainnya. Dalam segi modal atau pembiayaan, usaha pertanian organik relatif kecil dan hampir semua lapisan masyarakat bisa melakukannya. Modal dapat ditekan seminimal mungkin, karena tidak perlu membeli pupuk, obat-obatan dan sarana produksi lainnya.

\section{Tahap Bertani (Menjaga)- Pemberantasan Hama}

Petani masyarakat Dayak Kanayatn tidak menggunakan pestisida untuk membasmi hama atau penyakit. Salah satu unsur yang terdapat dalam sistem budaya dan kepercayaan nenek moyang masyarakat Dayak adalah nilai dan sikap yang menekankan manusia sebagai bagian yang integral dari alam (Fridolin Ukur, 1994). Berdasarkan nilai budaya tersebut, anggota kelompok suku Dayak dilarang membunuh hewan yang tidak membahayakan mereka maupun tidak menghancurkan sumber-sumber alam lainnya secara serakah. Untuk meng-hindari hama, petani masyarakat Dayak lebih banyak menggunakan berbagai ramuan dari tumbuhan yang diyakini dapat mengusir hama atau penyakit. Untuk lahan basah dilakukan 
menabur cincangan buah maja ke setiap saluaran air yang mengairi sawah, untuk membasmi serangan anjing tanah (salodok/orong-orong) dan ulat. Memasang ikatan sereh wangi disetiap saluran air, untuk mencegah serangan jamur dan ulat. Bila ditemukan ada serangan tikus, disetiap petak sawah diberi daun nanas yang diolesi kapur sirih dan minyak/lemak ular, agar kelihatan seperti ular pada malam hari dan membuat tikus takut.

\section{Penyediaan pupuk-Cara-cara pembuatan pupuk alami}

Peningkatan produksi padi sejak paruh kedua tahun 1980-an berlangsung dengan laju yang semakin rendah, tidak lain karena penggunaan pupuk kimia merusak mutu tanah dan penggunaan obatobatan (racun) telah memicu resistensi hama dan penyakit tanaman (Sitorus, 2006). Petani masyarakat Dayak tidak menggunakan berbagai pupuk sintetik dalam memelihara tanamannya. Untuk mendapatkan pupuk alami, pohon-pohon yang telah di tebang dan dipotong kecilkecil kemudian di bakar bersamaan dengan lahan yang akan dijadikan sebagai ladang nan-tinya. Untuk lahan kering, pupuk hampir tidak dilakukan karena sudah dianggap mencukupi dan disediakan oleh alam dengan melakukan penyiangan dan membiarkan rumput/ gulma yang dicabut dan digulung dengan rapi yang kemudian membu-suk sendiri. Petani-petani mengguna-kan abu dari kayu yang dibakar se-bagai pupuk yang sudah cukup untuk memenuhi kebutuhan padi di ladang. Untuk lahan basah dilakukan pene-basan gulma atau rumput, sisa gulma digulung kecil-kecil dan dipendam ke dalam tanah diantara rumpunrumpun padi yang berguna sebagai pupuk. Selain itu menaburkan pupuk kandang dari kotoran ayam/sapi dilahan pertanian, dan juga menaburkan abu dapur atau abu bekas pembakaran sampah dilahan pertanian.

\section{Pertumbuhan dan}

\section{Perkembangan Padi - Proses}

\section{Fotosintesis}

Di lingkungan pertanian, siswa dapat menyaksikan pertumbuhan dan per-kembangan padi mulai dari biji, buah, umbi dengan berbagai bentuk, warna, jumlah bulir padi dalam setiap tangkai. Selain itu, berbagai bentuk, panjang, lebar daun dan tinggi batang yang dapat menjadi petunjuk pada aktivitas fotosíntesis dapat diamati oleh siswa secara langsung.

\section{Tahap Menebang-Peran Cahaya/Fotosintesis}

Banyaknya sinar matahari yang mengenai ladang tergantung pada lindungan dari hutan yang berbatasan dan lamanya ladang memperoleh kesempatan terkena sinar matahari. Mengenai lindungan, jika ladang berbatasan dengan hutan yang masih lebat dan bukan ladang-ladang jenis yang lain, hutan yang berbatasan ini akan menghalangi masuknya sinar matahari ke tepi ladang yang akan dibakar. Oleh karena itu, tepi ladang tersebut setelah pembakaran hasilnya tidak akan sebaik tepi ladang yang lainnya. Jika dua keluarga atau lebih membuat ladang mereka dalam satu kelompok, berbatasan satu dengan lainnya pada dua sisi atau lebih, maka sedikit sisi ladang yang akan 
berbatasan dengan hutan yang tidak dibuka, sehingga ladang-ladang yang akan dibakar tidak banyak mendapat lindungan. Perbedaan pemerolehan cahaya ini berpengaruh pada produktivitas daun dan aktivitas fotosintesis, yang ditunjukkan dengan perbedaan bulir padi yang dihasilkan. Pemahaman tentang ini sudah dimiliki oleh petani, sehingga setiap keluarga petani masyarakat Dayak lebih suka memilih lokasi ladangnya berdekatan dengan ladang-ladang milik keluarga-keluarga lain. Namun, penjelasan ilmiah pengaruh intensitas cahaya pada produksi padi belum dimiliki mereka. Dari sudut anatomi dan morfologi, intensitas cahaya mempengaruhi bentuk dan antomi daun termasuk sel epidermis dan tipe sel mesofil (Vogelmann \& Martin, 1993, dalam Sopandie et al, 2004). Perubahan tersebut sebagai mekanisme pengen-dalian kualitas dan jumlah cahaya yang dapat dimanfaatkan oleh kloroplas daun. Daun tanaman yang ternaungi akan lebih tipis dan lebar daripada daun yang ditanam pada areal terbuka, yang disebabkan oleh pengurangan lapisan palisade dan sel-sel mesofil (Taiz \& Zeiger, 1991, dalam Sopandie et al, 2004). Naungan menyebabkan perubahan fisiologi dan biokimia antara lain ini telah teruji perubahan kandungan $\mathrm{N}$ daun dan kandungan Rubisko dan aktivitasnya. Enzim Rubisko berperan penting dalam fotosintesis yaitu mengikat $\mathrm{CO}_{2}$ dan dalam siklus Calvin perse-nyawaan Rubisko dengan $\mathrm{CO}_{2}$ menghasilkan 3-PGA. Intensitas cahaya dapat menyebabkan rendahnya ak-tivitas Rubisko (Bruggeman \& Danborn, 1993 dalam Sopandie et al, 2004).

\section{Pandangan Terhadap Alam Semesta-Pelestarian Hutan}

Dalam pikiran masyarakat Dayak dan Melayu di kabupaten Pontianak sebe-narnya memiliki sentuhan yang men-dalam dengan alam lingkungan sekitar. Oleh sebab itu, jika mereka bijaksana menata alam mereka akan mendapat rezeki dari alam, dibantu dan bahkan akan dilindungi oleh alam. Hal ini ada kaitannya dengan pan-dangan mereka, yang menganggap bahwa alam itu, baik yang nyata maupun yang gaib, merupakan sumber dan basis kehidupan. Adanya pandangan tentang alam sebagai basis kehidupan, menyebabkan masyarakat dayak dan melayu pada lingkungan pertanian di kabupaten Pontianak merupakan bagian yang tidak terpisahkan dari lingkungan itu sendiri. Manusia dengan alam memiliki kekuatan dan kekuasaan yang saling mendukung untuk menjaga keseim-bangan alam semesta. Alam pikiran mereka yang semacam ini, dalam kehidupan sehari-hari terimplementasi dalam praktek tradisi dan upacara adat, termasuk perilaku mereka dalam pengelolaan sumber daya hutan. Model kearifan pengelolaan sumber daya hutan ini telah diterapkan ratusan tahun secara turun temurun, sehingga praktek kearifan tradisional ini terbukti kelestariannya (Roedy Haryo W, 1998:73).

\section{SIMPULAN DAN SARAN}

1. Simpulan

a. Masyarakat tradisional lingkungan pertanian suku Melayu dan Dayak memiliki nilai-nilai tradisional dalam bertani yang terekspresikan melalui berbagai 
upacara adat, tata cara, mitos, etika, dan filosofi hidup.

b. Konsep-konsep tradisional yang ter-identifikasi dari masyarakat Melayu dan Dayak lingkungan pertanian yang dapat diintegrasikan dengan sains sekolah di SD, antara lain konsep varietas padi lokal-Saling Ketergan-tungan/Pelestarian Sumber Daya Alam, pemilihan tempat tanam-Keseimbangan Alam; ladang berpindah-Rantai Makanan/Ekosistem /Sumber Daya Alam; tahap bertani (pemupukan)-Kesuburan tanah, Tahap Bertani (Menjaga) Pemberantasan Hama; penyediaan pupuk - Cara-cara pembuatan pupuk alami; pertumbuhan dan perkembangan padi - Proses Foto-sintesis; tahap menebang-Peran

Cahaya/Fotosintesis; ladang di tempat rindang-peran cahaya; pandangan terhadap alam semesta-pelestarian hutan.

3. Salah satu model pembelajaran yang dapat mengakomodir budaya lokal adalah pembelajaran sains berbasis budaya lokal.

\section{Saran}

a. Dalam pembelajaran di kelas hendak-nya guru memperhatikan dan peduli terhadap latar belakang budaya siswa, karena keberhasilan proses pembelajaran IPA di sekolah sangat dipengaruhi oleh latar belakang budaya yang dimiliki oleh siswa atau masyarakat di mana sekolah tersebut berada. b. Pemberlakuan otonomi daerah hendak-nya dapat memberikan peluang kepada pemerintah daerah melalui Dinas Pendidikan di tingkat propinsi dan tingkat kota atau kabupaten untuk mengembangkan kurikulum dan bahan ajar dalam mengakomodasi potensi dan keunggulan daerah. Perlu dibentuk tim pengembang kurikulum yang dapat mengembangkan kurikulum IPA yang mengintegrasikan muatan Sains tradisional (ethnoscience) dalam pembelajaran, sehingga belajar sains menjadi lebih bermakna dan kontekstual.

\section{DAFTAR PUSTAKA}

Adimassana,YB. (2000). Revitalisasi Pendidikan Nilai di dalam Sektor Pendidikan Formal. Kanisius. Yogyakarta.

Arifianto. S. (2008). Etnosains dalam Penelitian Media

Lokal.http:// bisnis-journals. blogspot.com/ 2008/06/pendekatan-etnosainsdalam-penelitian.html.Diakses pada tanggal 15 April 2008.

Ahimsa-Putra, H.S. (2008). Wawasan Bu-daya untuk Pemberdayaan Penge-tahuan dan Teknologi Etnik/Lokal. Makalah disampaikan dalam Kongres Kebudayaan yang dise-lenggarakan oleh Kementrian Kebudayaan dan Pariwisata di Bukit Tinggi Sumbar, 19-22 Oktober 2003. http://melayuonline com/ind/article/read/141/etnosa insdan-etnoteknologi. Diakses pada tanggal 15 April 2008. 
Baker, D, et al. (1995). The effect of culture on the learning of sciencve in non-Western Countries: The results of Integrated Research Review. International Journal Science Education. Vol 17 (6).

Cobern, W. W., 1994. Constructivism and nonWestern science education research. International Journal of Science Education(16), 1-16.

Cobern, W.W. \& Aikenhead, G.S. (1998). Cultural Aspects of Learning Science. SLCSP Working Paper \#121. http:www.wmich.edu/slcsp 121.htm/ June 2002.

Depdiknas. (2001). Bahan sosialisasi pengembangan kurikulum berbasis kemampuan Dasar Sekolah Menengah Umum. Jakarta: Dirjen Dikdasmen Depdiknas.

Faisal. (1990). Penelitian Kualitatif. Malang. YA3.

Fadli, M. (2008). Pembelajaran Berbasis Budaya: Suatu model Pembelajaran. Ed. Upper Saddle River, New Jersey:Merill-Pretice Hall. http://209.85.175.104/ search?q=cache:tSlvhSSOSeEJ :genpositif.org/. Diakses tanggal 17 April 2008.

Hairida. (2008). STS : Peningkatan

Kualitas Proses dan Hasil Belajar Siswa. Proseding Seminar Nasional. ISBN:978979-993-3-6 Mei 2008. FMIPA UNY

Yogyakarta.

George, J. (2001). Culture and Science Education: Developing World. http://www.id21.org/education/ e3jglg2.html.

Indra Djati Sidi. (2001). Strategi Pendidikan Nasional. Makalah disajikan dalam Simposium dan Musyawarah Nasional I Alumni Program Pasca Sarjana Universitas Negeri Malang tanggal 13 Oktober 2001.

Jalal, F. dan Supriadi, D., (2001). Reformasi Pendidikan dalam konteks Otonomi Daerah. Yogyakarta: Adicita Karya Nusa.

John Weintré. (2004). Makalah Studi Lapangan:Beberapa Penggal Kehidupan Dayak Kanayatn (Kekayaan Ritual dan Keaneka-Ragaman Pertanian Hutan Kalimantan Barat. ) Pusat Studi Kebudayaan UGM Jogyakarta.

Moleong, L.J. (1990). Metodologi Penelitian Kualitatif. Bandung: PT Remaja Rosdakarya.

Patton, M.Q. (1982). Qualitative Evaluation Methods. Beverly Hills:Sage Publications.

Pannen, P. (2002). Faktor-faktor Perancangan Pembelajaran MIPA Berbasis Budaya. Makalah disampaikan dalam Seminar Nasional "Meningkatkan Kualitas dan Produktivitas SDM melalui Teknologi Pembelajaran" yang diselenggarakan oleh Ikatan Profesi Teknologi Pendidikan Indonesia. Jakarta, 18-19 Juli 2002.

Roedy, H.W. (1998). Masyarakat Dayak Menatap Hari Esok. Jakarta: Grasindo.

Sholahuddin, A.2001. Pemberdayaan Mata Pelajaran IPA dalam Upaya Menumbuhkembangkan 
Sikap Positif terhadap Lingkungan. Jakarta : http: //www.tutor.com.

My/tutor/content.asp. 28

Desember 2004.

Snively, G \& J. Corsiglia. (2001). Discovering Indigenous Science: Implications for science Education. Science Education. Vol. 85 (1). P. 7-34.

Suastra, W. (2003). Implementasi Pembelajaran Sains Berbasis Inkuiri di SLTP. Laporan Penelitian. IKIP Negeri Singaraja.

Sukmadinata, A.A. (1997). Pengembangan Kurikulum. Bandung: Penerbit PT Rosda Karya

Sopandie, D., Khumaida, N., Yahya, S. (2004). Pemberdayaan Aspek Fisiologi Fotosintesis Tanaman Padi dalam Upaya Peningkatan

Produksi:Adaptasi terhadap Intensitas Cahaya Rendah. Makalah pada Seminar IPTEK Padi, Subang.

Sri Astuti Rais. (2004). Eksplorasi Plasma Nutfah Tanaman Pangan di Provinsi Kalimantan Barat. Buletin Plasma Nutfah Vol.10 No.1 Th.2004. Balai Besar Penelitian dan Pengembangan Bioteknologi dan Sumberdaya Genetik Pertanian, Bogor

Wahyudi (2003). Tinjauan Aspek Budaya Pada pembelajaran IPA : Pentingnya kurikulum IPA Berbasis Kebudayaan Lokal.http:// www.depdiknasgo.Id/jurnal 40editorial40.htm.

Wuryadi.(2003).Paradigma Baru Pen didikan Sains. Jurnal Cakrawala Pendidikan.
Yogyakarta:Lembaga

Pengabdian

Masyarakat UNY
Kepada 
